\title{
Karst geohazards in the UK: the use of digital data for hazard management
}

\author{
A R Farrant and A H Cooper \\ British Geological Survey, Keyworth, Nottingham, NG12 5GG, Great Britain. \\ * corresponding author e-mail : arf@bgs.ac.uk
}

\begin{abstract}
An essential pre-requisite for any engineering or hydrogeological investigation of soluble rocks is the identification and description of dissolution features such as stream sinks, springs, sinkholes and caves. The British Geological Survey (BGS) is creating a National Karst Database that records such features across the country. The database currently covers much of the Carboniferous Limestone, the Chalk and particularly the Permo-Triassic gypsum and halite where rapid, active dissolution has caused significant subsidence and building damage.

In addition to the identification of specific karst features, the BGS has created a National Karst Geohazard Geographical Information System (GIS). This has been guided by the National Karst Database and created by identifying all the soluble lithologies from the BGS 1:50 000 scale digital geological map and giving each a score, based on factors including lithology, topography, geomorphic position and superficial cover deposits. This national zonation of the soluble rocks can be used to identify areas where the potential for karstic features to occur is significant and where dissolution features might affect the stability of buildings and infrastructure, or where karstic groundwater flow might occur. Both datasets are invaluable scientific tools that have been widely used to support site investigation, groundwater investigations, planning, construction and the insurance businesses.
\end{abstract}

$\begin{array}{ll}\text { Word Count } & 7530 \\ \text { No. References } & 34 \\ \text { No. Tables } & 7 \\ \text { No. Figures } & 8 \\ \text { Abbreviated title: } & \text { Karst geohazards in the UK }\end{array}$

Karst features, developed over and within soluble rocks, are a well-known potential geohazard, and can cause significant engineering problems, such as subsidence and irregular rockhead. These can pose difficulties for planning and development and be very costly for the construction and insurance industries. There have been numerous examples of subsidence and infrastructure damage resulting from settlement and or collapse of karst features (Waltham et al., 2005); in extreme cases they can cause properties to collapse and put lives at risk. More commonly, karstic rocks can make ground conditions more difficult, increasing construction costs. Underground cavities can also act as pathways along which hazardous liquid and gaseous contaminants can travel, commonly some distance from their source, thus posing an environmental risk.

Databases and maps of karst hazards are important for understanding the severity of the problem, and they constitute useful tools for hazard avoidance that have relevance to planning, engineering, development and the insurance industry. Developers, planners and local government can only operate effectively if they have advance warning about the hazards that might be present and have access to relevant geological information.

In the UK, karst is most typically associated with the locally varied limestone successions of Early Carboniferous age, referred to informally as the Carboniferous Limestone, but karst features are also found in a host of other carbonate and evaporite lithologies throughout the geological column (Fig. 1).

\section{Palaeozoic and Neoproterozoic limestones}

The oldest karstic rocks in the UK are the thin metacarbonate beds preserved within parts of the Dalradian Supergroup of the Scottish Highlands. The features here are perhaps analogous to the Scandinavian stripe karst (Lauritzen, 2001) Numerous small caves, sinkholes, stream 
sinks and springs have been recorded in the Appin and Schiehallion regions (Oldham, 1975). However, many of these are in remote upland areas and generally pose little risk to infrastructure. Elsewhere in north-west Scotland, Cambrian to Ordovician limestones and dolomites belonging to the Durness Group crop out in a long narrow belt along the line of the Moine Thrust and on Skye. Several extensive well developed cave systems, for example the Allt nan Uamh system, and those in the Traligill valley have been described (for example, Lawson 1988, Waltham et al., 1997), although again many of these are in remote upland areas.

Farther south, minor dissolution features and enlarged fractures have been identified from limestones of Wenlock (Silurian) age in the West Midlands and the Welsh Borders, but no significant cave systems are known. Limestones of Devonian age crop out in parts of Devon, particularly around Plymouth, Buckfastleigh and Torbay. Several well-developed cave systems are known in these areas (Oldham et al, 1986), along with stream sinks, karstic springs, sinkholes (dolines) and areas of irregular rockhead. Problems with karstic cavities and buried sinkholes have been reported in the Plymouth area.

It is the Carboniferous Limestone that hosts the best-developed karst landscapes and the longest cave systems in the country. It occurs widely throughout western and northern England and in Wales, and karst features are present on and within the majority of the outcrop (Waltham et al, 1997). Particularly well-developed karst occurs in the Mendip Hills, around the northern crop of the South Wales coalfield (Ford, 1989), in the Derbyshire Peak District and in the Yorkshire Dales and adjacent areas, running up into the northern Pennines. Less well known karst areas include the Forest of Dean, the southern crop of the South Wales coalfield from Glamorgan through the Gower to Pembrokeshire, in North Wales around the Vale of Clwyd, and around the fringes of the Lake District. In all these areas, well-developed karstic drainage systems, sinkholes and extensive cave systems are common.

The major challenges associated with these karst areas are water supply protection, geological conservation and engineering problems. Subsidence associated with sinkhole formation is commonly encountered in remote and rural areas with little impact on property and infrastructure, but damage to houses, tracks and roads is locally a problem. Commonly of greater significance, many of these subsidence hollows are sites for illegal tipping of farm and other refuse or waste, which can cause rapid contamination of the groundwater and local drinking supplies (Fig. 2).

\section{Permian dolomites and limestones}

The Permian carbonates in the UK are dominated by magnesium-rich limestones and dolomites. The solubility of these rocks is lower than that of the pure limestones so karstic features are less-well developed. However the dolomites are closely associated with gypsum which is heavily karstified. Numerous small cave systems are present along the outcrop of the magnesian limestones from near Mansfield in the south to Sunderland in the north. Some sinking streams are present as are numerous springs, but very few sinkholes occur (possibly due to infilling by agricultural practices over the centuries) and the rock is generally not problematical for engineering purposes. However, numerous open joints, incipient conduit systems on bedding planes, palaeokarst, and sediment infilled fissures can be identified in road cuttings and quarries. Hydrogeologically it is a minor to moderatelysized aquifer subject to pressure from pollution and development, especially landfill contamination from former quarries.

In Mendip, South Wales and parts of Devon, limestone-rich Permo-Triassic conglomerates (predominantly, but not exclusively derived from Carboniferous limestone uplands) also host cave systems, perhaps the most famous example being Wookey Hole in Somerset.

\section{Jurassic limestones}

Jurassic limestones extend across much of central, southern and eastern England in a belt from Dorset to North Yorkshire, and in parts of western Scotland. Although the karst in these 
rocks is not as well developed as in the more massive Palaeozoic limestone, karst features do occur, particularly in some of the Portlandian and Purbeck limestones in Dorset and Wiltshire, in the Cornbrash, and in the Corallian limestones around Oxford and on the southern flank of the North York Moors. Karst is also well developed in the Lincolnshire Limestone south of Grantham (Hindley, 1965). Here, water supply protection is the main issue, although localized subsidence and areas of irregular rock-head do occur.

\section{Cretaceous Chalk}

The Chalk is the most widespread carbonate rock in the country and of immense importance for water supply. It forms the UK's most important aquifer. Karst features occur in many parts of the Chalk outcrop, particularly along the margin of the Palaeogene cover (Farrant, 2001). In these areas, the development of dissolutionally enlarged fissures and conduits can potentially cause problems for groundwater supply by creating rapid contaminant pathways though the aquifer. This is particularly important as parts of the Chalk outcrop underlie major transport corridors and urban areas. Chalk dissolution also generates subsidence hazards and difficult engineering conditions associated with the development of clay filled pipes and fissures. These problems include irregular rockhead, localized subsidence, increased mass compressibility and diminished rock mass quality. Well developed karstic groundwater flow systems occur in Dorset, near Salisbury, around Newbury and Hungerford and in many parts of the Chilterns, particularly along the Palaeogene margin between Beaconsfield and Hertford (Waltham et al., 1997).

\section{Triassic and Permian Salt}

In the United Kingdom, halite, or rock salt, occurs mainly within the Triassic strata of the Cheshire Basin, and to a lesser extent in Lancashire, Worcestershire and Staffordshire. It is also present in the Permian rocks of north-east England and Northern Ireland (Notholt and Highley, 1973).

Where the saliferous Triassic rocks come to outcrop, most of the halite has dissolved and the overlying and interbedded strata have collapsed or foundered producing a buried salt karst. These areas commonly have saline springs, indicative of continuing salt dissolution and the active nature of the karst processes. The salt deposits were exploited using these springs from before early Roman times to Victorian times when more intense brine and mined salt extraction was undertaken. Halite dissolves rapidly and subsidence, both natural and mininginduced, has affected the main Triassic salt fields including Cheshire, Staffordshire (Stafford), Worcestershire (Droitwich), coastal Lancashire (Preesall) and parts of Northern Ireland. Much of the mining has been by shallow brine extraction, the results of which mimic the effects of natural karstification of the salt deposits.

Permian salt is present at depth beneath coastal Yorkshire and Teeside. Here the salt deposits and the karstification processes are much deeper than in the Triassic salt. The salt deposits are bounded up-dip by a dissolution front and collapse monocline (Cooper 2002). The depth of the salt dissolution means that very few karstic features are present at the surface though some dissolution mining subsidence has occurred.

\section{Triassic and Permian gypsum}

Compared with the British limestone karst, gypsum karst occurs in relatively small areas. It is present mainly in a belt $3 \mathrm{~km}$ wide and about $100 \mathrm{~km}$ long in the Permian rocks of eastern and north-eastern England (Cooper, 1989). Significant thicknesses of gypsum also occur along the eastern side of the Vale of Eden (Ryder and Cooper, 1993). It also locally occurs in the Triassic strata (Cooper and Saunders, 1999), but the effects of karstification are much less severe than in the Permian rocks. The difference is mainly caused by the thickness of gypsum in the Permian sequence and the fact that it has interbedded dolomite aquifers. In contrast the Triassic gypsum is present mainly in weakly permeable mudstone sequences. The gypsum karst has formed phreatic cave systems, but the rapid solubility rate of the gypsum (Klimchouk, et al., 1997) means that the karst is evolving on a human time scale. Active 
subsidence occurs in many places, especially around the town of Ripon (Cooper, 1986, 1989, 1998) and to a lesser extent in the eastern part of Darlington (Lamont-Black et al., 2002); it also occurs in several other locations along the outcrop. The active nature of the dissolution and the ongoing subsidence features cause difficult ground conditions for planning and development (Paukstys et al., 1999; Cooper and Saunders, 1999). Gypsum palaeokarst features also occur, especially along the coast of north-east England and in the Firth of Forth off eastern Scotland (Cooper, 1997).

\section{The National Karst Database}

Geologists and engineers have recognized for some time that the availability of baseline data is essential for the assessment of geological hazards. Understanding the severity of the problem is a pre-requisite for hazard avoidance. Developers, planners and local government can plan accordingly if they have advance warning about the hazards that might be present and have access to relevant geological information. Guidance for the development of unstable land is written into British Government planning policy in the "Planning Policy Guidance note 14: Development on unstable land" (Department of the Environment 1990), and the supplementary “Annex 2" (Department of Transport, Local Government and the Regions 2002).

When this policy was implemented, rudimentary baseline data were collected in an initial database of natural cavities commissioned by the Department of the Environment and produced by a private consultancy, Applied Geology Limited (1993). This is now held, and maintained as a legacy dataset by the British Geological Survey (BGS), and by Peter Brett Associates, a private geological consultancy. This study showed the national distribution of karst and other natural cavities, based on documentary evidence from a wide variety of sources. However, in many cases the spatial recording was not very accurate, commonly only to the nearest kilometre, and in many cases only the barest minimum of data was collected. Furthermore, the database was over-complex and many of the database fields remained empty. Additionally, recent mapping, particularly in Chalk terrains has shown that the previously available data severely under-represents the density of karst features present. Moreover, many more karst features have been identified since 1993, both by more recent geological mapping, but also through the advent of more sophisticated remote sensing techniques such as LiDAR (Light detection and ranging). Cavers have also opened up many new cave systems, including one of Britain's longest cave systems, Ogof Draenen near Blaenavon (Farrant, 2004), now over $70 \mathrm{~km}$ long, and the country's deepest natural shaft, the 145m-deep Titan shaft in Derbyshire's Peak Cavern. Studies of cave systems can provide useful insights into the potential for karst geohazards to develop in the surrounding area (Klimchouk and Lowe, 2002).

Much of the information in the Applied Geology dataset came from published BGS maps, memoirs and reports. However, additional information is available on unpublished field slips and notebooks held in the National Geological Data Centre in Keyworth. Karst features have been recorded routinely by field geologists on their field slips since the Survey's inception in 1835. However, they are rarely shown on published map and reports, and the data contained on them can be difficult to access.

In 2000, as part of a drive to make its datasets more accessible, the BGS embarked on constructing a more comprehensive Geographic Information System (GIS) and database of karst information (Cooper et al. 2001), from which the National Karst Database was set up. The aim was to retrieve the karst data contained in the field slips and on paper maps held in the archives, and make them accessible in a GIS format. The BGS field slips and maps have now been scanned and many of them geo-rectified so that they can be viewed via an in-house customized GIS system. An example of a historic field slip from Lincolnshire is shown in Fig. 3.

Additional information is gathered both in the field and from existing documentary data sources. The information gathered during fieldwork is either recorded digitally on portable 
tablet computers or on pro forma field data sheets that have the same data fields as the GIS and its underlying database. Documentary information is gathered from existing datasets such as scanned and georectified copies of the geologists' field maps, historical and modern georectified Ordnance Survey maps, cave surveys, academic papers and historical documents. The data are entered into a customized GIS system, initially achieved using ArcView3 (Cooper et al. 2001), but now using ArcGIS9. The point information and database tables are then copied to centralized Oracle databases. Other datasets such as the Applied Geology database and the Mendip Cave Registry data are being used to identify other sources of information where relevant.

Data on five main types of karst feature are collected: sinkholes (or dolines), stream sinks, caves, springs, and building damage. The details gathered are listed in Tables 1 (sinkholes), 2 (springs), 3 (stream sinks), 4 (caves) and 5 (building damage). For each of these datasets, in common with all BGS databases, the information added to the system has common header data including National Grid co-ordinates, date entered, user ID and reliability.

For sinkholes, the data can be entered either as a polygon, where spatial data exist, or as a point where the sinkhole is too small to be represented or if no spatial data are available. The type description of sinkhole is adapted from the classification of Culshaw and Waltham (1987). The size of springs and stream sinks is necessarily subjective, depending on the time of year and rainfall, but a proxy for the average flow can be obtained from the channel width and depth. For the majority of historical information gathered from published maps and geologists' field maps, no precise description of spring or stream sink flow is given. Information gathered for caves is also collected as either point data for cave entrances, or if it is known, as linear data for the approximate centre lines of the caves themselves. It is possible to include full cave surveys, but there are often copyright issues that need to be addressed before these can be used. Many sites are multiple features, for example many stream sinks are also cave entrances, whereas sinkholes might also be sites of building/infrastructure damage.

Since the database was set up much information has been added to the system. Data covering most of the evaporite karst areas of the UK have now been added, along with data covering about $60 \%$ of the Chalk, and $30 \%$ of the Carboniferous Limestone outcrops. To date over 800 caves, 1300 stream sinks, 5600 springs and 10000 sinkholes have been recorded, and many of the classic upland karst areas have yet to be included.

\section{Other Karst Datasets}

Other karst datasets are available, most of which have been collated by members of the caving community. These data generally cover the more well-known Carboniferous and Devonian limestone karst areas, which contain most of the accessible caves.

The British Caving Association (BCA) maintains a registry of karstic sites in the form of a National Cave Registry. It holds limited information about each site with links to more comprehensive information in regional cave registries maintained by regional caving organizations, including the Mendip Cave Registry and the Cambrian Cave Registry. The Mendip Cave Registry is manned by volunteer registrars who form the membership of the group. Its aim is to record all available information relating to the caves and stone mines in the counties of Bristol, Somerset and Wiltshire. It has around 8000 documented sites of speleological interest. These include caves, stream sinks, springs and sites where cavers have dug in their efforts to discover new caves. The Cambrian Cave Registry is currently being digitized and is scheduled to be available on-line sometime in 2007. The Black Mountains Cave Register, part of the Cambrian Cave Registry, used to be accessible on-line, but is no longer available. The regional caving councils, supported by the BCA, also hold databases containing information about caves and access arrangements.

The Cave Database (http://www.cavedatabase.co.uk/) is an open access website to which anyone can add cave-related links. However, its coverage is patchy, and the data not 
complete. In addition, the website may be at risk of being compromised by the gratuitous inclusion of links that are not cave related, or data that has not been checked.

CAPRA, the Cave Archaeology and Palaeontology Research Archive based in the University of Sheffield, has compiled a gazetteer of English, Scottish and Welsh caves, fissures and rock-shelters that contain human remains. This is available on the CAPRA website (Chamberlain and Williams, 1999; 2000a; 2000b).

The Chelsea Spelaeological Society has compiled a dataset of natural and man-made cavities in south-east England. These have been published as a series of paperback publications (some co-authored with the Kent Underground Research Group) that are available from the Society. Most of the data relate to dene-holes and Chalk mines, but some natural chalk caves are included, such as those at Beachy Head in Sussex (Waltham et al., 1997).

Many of the lesser known karst areas, including much of the Chalk outcrop, are not covered by these schemes. These areas still contain significant densities of karst geohazards, and are commonly located in more densely populated areas. Moreover, a significant drawback of these databases is that they only provide information on known karst features. Predicting the whereabouts of karst features such as buried sinkholes and undiscovered near-surface cavities is more difficult. Combining available baseline karst data with other digital spatial data, such as bed-rock and superficial geology, superficial deposit thickness and digital terrain models, within a Geographical Information System can provide a powerful tool for predicting karst geohazards.

\section{National Karst Geohazard Geographical Information System (GeoSure)}

Over the past decade, the BGS has invested considerable resources in the production of digital geological map data for the UK. Digital geological maps (DiGMap) are now available for most of the country at the 1:50,000 scale, and complete coverage at the 1:250,000 and 1:625,000 scales. A significant part of the country is also covered at the 1:10,000 scale. All these datasets include the bedrock and the 1:625,000, 1:50,000 and 1:10,000 scale datasets also include data for the superficial deposits. Each polygon of digital geological data is attributed with a two-part code (the LEX-ROCK code) that gives its stratigraphy and its lithology. For example, the Seaford Chalk Formation is represented by the code SECK_CHLK, whilst the Carboniferous Gully Oolite Formation has the code GUO_OOLM. A comprehensive list of all the LEX codes used can be found in the BGS Lexicon of Named Rock Units, which is available on the Internet at http://www.bgs.ac.uk/lexicon/ lexicon_intro.html. Here, each named unit will eventually be defined and its upper and lower boundaries described. The lithological codes (ROCK) are based on the BGS Rock Classification Scheme and are also explained and listed on the Internet at http://www.bgs.ac.uk/data/dictionaries.html and can be searched by name or code.

The availability of the digital geological maps has enabled the BGS to produce a set of predictive datasets for geological hazards, known and marketed as "GeoSure". Several derived datasets have been produced using a variety of algorithms to provide geohazard data for soluble rocks (dissolution); landslides (slope instability); compressible ground; collapsible rocks; shrink-swell deposits and running sand.

The dissolution dataset can be used to identify areas where there is potential for a range of karstic features to develop. Such features include potential geohazards such as sinkholes, dissolution pipes, natural cavities and areas prone to dissolution-generated irregular rockhead, as well as hydrological features such as stream sinks, estavelles and karstic springs. It can also be used to highlight areas where karstic groundwater flow might be significant.

The first iterations of a karst hazard GIS used the bedrock codes as the basis for a purely lithology-based system that was enhanced by local knowledge and manual subdivision. More recently, a domain-based scoring system in a GIS environment has been developed using a range of additional datasets. This has several advantages over the purely lithology-based system. It allows greater flexibility in rating hazard levels, and can give a more precise hazard 
rating for a given area. It allows differential weighting to be given to different controlling factors depending on the underlying karstic lithology. It is a more robust system and can be tailored to the quality of the input data.

\section{Methodology}

The GeoSure dissolution layer has been created by identifying a suite of factors that can influence the style and degree of karst features likely to develop at any one place. Each of these factors, such as bedrock lithology, geomorphological domain and superficial deposit thickness is represented in the GIS as a separate theme or layer. Each of these themes is then categorized and given a score, to give an indication of the contribution it might make to the overall degree of soluble rock hazard, in a similar manner to the more detailed site specific method for the Chalk proposed by Edmonds (2001). Those with a strong influence will have a high score, those with a slight influence will have a low score. Some factors, such as very thick superficial deposit cover, might even have a negative score if they significantly reduce the potential for karst features to develop.

The karst geohazard layer is created in the GIS by intersecting all the datasets into one, creating a mosaic of intersected polygons. For each resulting polygon, the sum total of each of the contributing factors is then used to give an overall potential hazard score. These scores can then be categorized to give a hazard rating (A-E) for a particular area. The hazard rating categories can be tailored to suit the different end-users; for example, a high hazard rating important for those planning a tunneling scheme might not be pertinent for a home owner. The geological manifestations of carbonate karst compared with gypsum and salt karsts are different, so the evaporites have a slightly different set of parameters and are calculated separately. In addition, the actual scores used for each factor can be updated when new or more detailed base-line information, such as a new version of the digital geological map, becomes available.

\section{Bedrock Lithology}

The type, style and scale of karst geohazard is strongly influenced by bedrock lithology, which can commonly be used as a proxy for a particular rock unit's overall mass fracture properties and hydrological characteristics.

All the known soluble and karstic rocks (with the exception of units containing gypsum and halite, which are described later) were extracted from the BGS DiGMap 1:50 000 scale digital geological database and grouped on the basis of their LEX-ROCK codes into four broad lithological groupings: Cretaceous chalks; Palaeozoic limestones (including Neoproterozoic metacarbonates); Jurassic limestones and oolites, and Triassic conglomerates and Permian dolomites.

These broad grouping reflect the different style of karst landscape evolution that these rock units support. For example, the style and type of karst features developed on the Chalk is quite different from that developed on the Carboniferous Limestone.

Each of the 480 individual geological units extracted from the DiGMap database was then given a score based on its LEX-ROCK code. Highly karstic rocks such as some of the Carboniferous Limestone units are given a high score, whereas less karstic, but still soluble rocks, such as some of the Jurassic oolites, have a lower score. The rest of the guiding factor datasets were then cut against the bedrock layer to create the final hazard layer specific to the karst areas of the UK. The scores used to weight each of the guiding factors can be adjusted slightly according to the lithological groupings to reflect the style and degree of karstification.

In addition, a set of non-soluble lithologies that are known to host karstic features were also extracted. In areas of interstratal karst, the overlying cover rocks are liable to subside into cavities in the underlying limestone, creating cover-collapse sinkholes. The Twrch Sandstone Formation (Marros Group, which replaces the term Millstone Grit in South Wales) is a classic example of a non-soluble lithology that locally hosts sinkholes and stream sinks. 


\section{Superficial Deposit Domains}

The superficial geology of an area has a strong influence on the development of karst features. Areas with a thin cover of superficial deposits commonly have a greater incidence of near surface karst features such as suffosion sinkholes. This is because the cover serves to concentrate surface runoff, generating discrete point recharge into the underlying bedrock, and concentrating dissolution. The unconsolidated deposits can also slump and ravel into dissolutionally enlarged fissures in the underlying limestone, creating dissolution pipes, cavities and, ultimately, sinkholes. These types of sinkhole are common in areas with a thin cover of glacial till overlying the Carboniferous Limestone, as in the Yorkshire Dales, or areas of clay-with-flint over the Chalk in southern England.

Details of all the superficial deposits that overlie soluble bedrock polygons were extracted from the BGS DiGMap 1:50 000-scale digital geological database and cut against the soluble bedrock polygons. The superficial polygons were then grouped into a set of superficial deposit domains that reflect their genetic origins (Table 6), based on LEX-ROCK codes. Each of these domains is given a score. In the case of marine superficial deposits the score is negative, which reflects the lower potential for karst to develop in areas covered by marine deposits such as estuarine alluvium.

\section{Superficial Thickness}

Each superficial unit will also have a score depending upon how thick it is. Areas with a very thin superficial cover will have a high score, reflecting the greater likelihood of point recharge and the formation of sinkholes, with lower scores the thicker the units get. For superficial deposit thicknesses greater than a specified limiting value the score will become negative, reflecting their negative influence on the development of sinkholes. The influence of superficial deposits on the development of karst features is clearly demonstrated in the Yorkshire Dales. Here, limestone areas with a thick glacial till cover (for example beneath drumlins), generally have very few sinkholes (although relict sediment filled palaeokarst features may be preserved beneath the till), whereas areas with a thin superficial cover are commonly pockmarked with suffusion sinkholes. The superficial thickness is taken from the BGS Superficial Deposits Thickness Model, divided into 6 categories, and scored accordingly.

\section{Superficial Permeability}

The permeability of the superficial deposit also has an affect on the likelihood of dissolution features developing in the underling bedrock. Highly permeable units such as sandy river terrace deposits have higher a score than lower permeability clay-rich deposits. This reflects the ease with which the water can flow through the deposit, creating an irregular rockhead and dissolution pipes at the bedrock interface. The permeability information is derived from the BGS Superficial Permeability database and has been divided into four categories and scored accordingly.

\section{Slope Angle}

A nationwide digital slope model has been created using NextMap ${ }^{\mathrm{TM}}$ data. The slope angles have been categorized into a range of values, cut against the bedrock theme and scored accordingly. Flat or gently sloping areas will have the highest score, principally because it is in these areas in the UK that sinkholes, dissolution pipes and areas of irregular rockhead are most likely to develop. On steeper terrains, slope process tend to erode karst features rather than enhance them.

\section{Glacial Limit}

The limits of the extents of the Devensian and Anglian glaciations have a minor influence on the degree of karstification in the UK. In areas south of the glacial limits, many relict karst features occur, preserved on the landscape. In contrast, areas within the limit of the last Devensian glaciation have been subjected to locally extensive erosion and many karstic 
features developed in the Pleistocene interglacials have been eroded away. This dataset divides the country into polygons defined by the various recognizable glacial limits (Anglian, Devensian and Loch Lomond). Areas outside the maximum glacial limit will have the highest score as they will be most weathered.

\section{Expert GIS polygons}

In addition to the polygons derived from existing digital datasets, three new datasets characterizing the relationship between a soluble rock and adjacent impermeable strata were created (Fig. 4). These three polygon sets have been created manually using digital geological and topographic maps, cave surveys, detailed local knowledge, the National Karst Database and expert overviews of karst geomorphology in general.

\section{Runoff Margin}

The greatest concentrations of potentially hazardous, surface karst features are commonly associated with margins between an impermeable and soluble lithologies, where runoff is directed onto the soluble rocks. There are several broad types of situation where this relationship can arise. It occurs where younger sandstones or mudstones overlie the soluble lithology, for example where the Palaeogene Reading Formation overlies the Chalk in southern England, or where the Twrch Sandstone Formation overlies the Carboniferous Limestone in South Wales. It also occurs in dipping strata where older rocks form the higher ground; a classic example is the contact between the Avon Group (Lower Limestone Shales) and the Carboniferous Black Rock Limestone Formation in the Mendips. Alternatively, a similar contact might arise due to faulting or an unconformity.

This zone of enhanced karst is represented in the GIS by a manually-picked polygon along the margin between a non-karstic rock and a karstic unit where the non-karstic rock is topographically higher.

\section{Feather Edge}

Karstic features also occur in non-karstic rocks that overlie a soluble lithology. Examples include the spectacular sinkholes (Fig. 5) developed on the Twrch Sandstone Formation on Mynydd Langynidr in South Wales (Waltham et al., 1997). These are caused by the collapse of the sandstone into cavities in the underlying Carboniferous Limestone, and can develop though a considerable thickness of cover strata. Similar, smaller features occur in the Reading and Thanet Sand formations overlying the Chalk (Edmonds, 1983). Karst features such as sinkholes, stream sinks and dissolution pipes are particularly common where the cover strata thin to a feather edge at the contact with the underlying soluble strata.

This zone is also represented in the GIS by a manually-picked polygon along the 'featheredge' of the impermeable deposit. This zone will be given a high score, as the bedrock lithology is generally insoluble and would otherwise have a very low score, for example the Reading Formation on the Chalk.

\section{Interstratal karst}

In parts of South Wales, the Forest of Dean and the Mendip Hills, significant areas of interstratal karst occur. This is where karstic drainage systems have developed in the Carboniferous Limestone below a significant thickness of impermeable rocks such as the Twrch Sandstone Formation or the Cromall Sandstone Formation in the Forest of Dean. There might be little or no surface expression of karst, but extensive caves or karstic groundwater flow systems can occur at depth, such as Ogof Draenen near Abergavenny (Farrant, 2004), and the Wet Sink - Slaughter Risings system near Joyford in the Forest of Dean (Waltham et al., 1997). Areas where interstratal karst is significant have been identified and digitized, making use of geological and topographical maps, groundwater tracing experiment results, cave surveys and expert local knowledge. 
All the above datasets are intersected with each other and the scores for each summed to create the final hazard layer. For example, a flat area of the Carboniferous Black Rock Limestone situated adjacent to an area of impermeable strata within the runoff area, with no superficial deposits in the Mendip Hills would score quite highly, and be given an E hazard rating. In contrast, an area of bare Carboniferous Black Rock Limestone on a moderate slope would generate a more modest score corresponding to a $\mathrm{C}$ rating. An area on the feather edge of Twrch Sandstone overlying the Carboniferous Limestone scores quite highly, putting it in a D hazard category. Similarly, an area of gently sloping Seaford Chalk with a thin cover of clay-with-flints would also score quite highly and be given a D rating, whereas an area of New Pit Chalk on a scarp slope would generate a low score, and be given an A rating. It is important to note that the scale, style and type of karst features present in each area may be different. Some smaller scale, less obvious karst features such as chalk dissolution pipes may pose more of an engineering hazard than some larger karst features such as deep caves.

Figure 6a,b shows an example from the Mendip Hills in Somerset where a mature karst landscape has developed on the Carboniferous Limestone. The greatest density of karst features occurs along the margin of the Avon Group mudstone and within a thin cover of Mesozoic strata capping the limestone, but some karst also occurs within the Triassic Mercia Mudstone Group conglomerates.

The information given to accompany the overall hazard ratings can then be tailored to suit the type of end user, be it a home owner, insurer or estate manager (Table 7).

\section{Gypsum and salt karst areas}

Gypsum and salt are so much more soluble than carbonate rocks that they tend to form buried and interstratal karst and the rocks themselves are rarely seen at the surface. For this reason many of the influences that can be factored in for the carbonate rocks do not apply to gypsum and salt. The lithology of the superficial deposits has less influence and slope angle is largely irrelevant. Superficial deposit thickness does have a bearing, but not until it is very thick and in areas where groundwater movement is restricted or below sea level. For salt- and gypsumbearing strata a slightly different methodology is being used; the scoring method is being investigated, but has not yet been quantified to make it practical. The technique used relates almost exclusively to the use of expert polygons, derived from the BGS digital geological map information, and enhanced by information from the National Karst Database and local or published knowledge, to define the problem areas.

\section{Permian gypsum-bearing strata}

The Permian gypsum sequence in eastern England forms an interstratal karst with thick sequences of gypsum sandwiched between dolomite aquifers. The main gypsum-bearing strata are the Hayton and Billingham anhydrite/gypsum sequences that equate in part to the Edlington and Roxby formations at outcrop. The Brotherton Formation dolomite sandwiched between the two gypsum sequences is heavily affected by karstic subsidence and collapse (Fig. 7) emanating from the underlying Edlington Formation/Hayton gypsum, but the dolomite itself only locally contains dissolution features. The amount of dissolution is controlled by the amount of water flow through the sequence; both river valleys and buried river valleys have a profound effect on the concentration of dissolution features. The most subsidence prone areas occur where these features cut through the sequence and where water feeds down-dip in the carbonate aquifers to emerge as sulphate-rich artesian springs in the valleys. Not enough digital information is currently available to characterize the hydrogeology, so the expert polygon approach is currently taken by utilizing the National Karst Database to determine the areas most susceptible to subsidence.

The National Karst Database enables the expert polygons for the feather edge zone to be identified so that the lower parts of the overlying non-karstic Sherwood Sandstone Group, which are prone to inter-stratal subsidence, are also included in the susceptible belt. The subsidence-prone zone is determined by combining the digitized geological outcrop limits of 
the Edlington, Brotherton and Roxby formations with this feather edge zone of the Sherwood Sandstone Group. The superficial deposits across much of the susceptible zone are very thick, but the thickness of gypsum is sufficient over most of the area for its dissolutional removal to cause subsidence to migrate upwards through the superficial cover to the surface, creating large sinkholes. In some places with thick gypsum, such as to the east of Darlington, where the superficial cover is extremely thick (30-40 m) and the ground level low, there is a lower hydrostatic head driving the system. Here there is less likelihood of point subsidence, but since the superficial deposits contain water-saturated sand lenses and beds, subsidence can occur by the limited flow of running sand into the underlying gypsum karst cavities. The result of this is the formation of large shallow bowl-shaped subsidence areas.

In the Vale of Eden the gypsum sequence is sandwiched between mudstones. Consequently less water reaches the gypsum, and karstic features occur mainly at the base of the superficial deposits or in areas where there is concentrated water flow towards local rivers and streams. Because of this, the outcrop of the A-B-C-D gypsum beds and the zones between them are amalgamated to produce a combined area. The Permian gypsum of the Vale of Eden and the anhydrite along the coast is included in this area.

For the Permian gypsum karst areas, the expert zones identified are:

$\mathbf{A}=$ Very Low, areas where gypsum is present, but the thickness of deposits are known to be thin, where the adjacent rocks are not aquifers and there is no recorded subsidence.

$\mathbf{B}=\mathbf{L o w}$, areas where gypsum is present in substantial thicknesses, but where the adjacent rocks are not aquifers and where there is no recorded subsidence.

C = Moderate, areas where gypsum is present in substantial thicknesses, where the adjacent rocks might or might not be aquifers, but where there is no recorded subsidence. Mainly the majority of the Permian gypsum in the Vale of Eden and some of the Permian gypsum of eastern England.

$\mathbf{D}=\mathbf{H i g h}$, areas where gypsum is present in substantial thicknesses, where the adjacent rocks are aquifers and where there is some recorded subsidence. Mainly the Permian gypsum of eastern England, including Darlington, Tadcaster and Church Fenton.

$\mathbf{E}=$ Very high, areas where gypsum is present in substantial thicknesses, where the adjacent rocks are aquifers, where buried valleys cut through the sequence and where there are numerous records of ongoing subsidence. Mainly the Permian gypsum of eastern England south of Darlington, Ripon, and Brotherton.

\section{Triassic gypsum-bearing strata}

Triassic gypsum-bearing strata are widespread, but mainly contain thick gypsum beds in the Staffordshire, south Derbyshire and south Nottinghamshire areas. Karstic features are sporadic with some caves, sinkholes and stream sinks present. In addition, some localized building damage has occurred. The expert zones defined for the Triassic gypsum are subdivided into:

A = Very Low, areas where gypsum is present, but the thickness of deposits are known to be thin, where the adjacent rocks are not aquifers, where the superficial cover is thick and there is no recorded subsidence. Mainly the Triassic Mercia Mudstone Group where fibrous gypsum and thin bedded gypsum has been recorded and the low-lying areas with thick superficial cover.

$\mathbf{B}=$ Low, areas where gypsum is present in substantial thicknesses, but where the adjacent rocks are not aquifers and where there is no recorded subsidence.

C = Moderate, areas where gypsum is present in substantial thicknesses, where the adjacent rocks or might not be aquifers, where there is no recorded active subsidence, but where subsidence features are present. Mainly the Triassic Mercia Mudstone Group where thick gypsum is present. 
D = High, areas where gypsum is present in substantial thicknesses, where the adjacent rocks might or might not be aquifers, and where there is some recorded subsidence.

\section{Permo-Triassic halite-bearing strata.}

The subdivisions applied to the salt areas are basically the same as those applied to the gypsum. The difference comes in the mechanisms of collapse and the fact that salt is much more soluble and much more rapidly dissolved than gypsum. The salt areas are all buried beneath considerable thicknesses of overlying brecciated and collapsed rock, or thick superficial deposits.

Hazard assessment of many of the salt areas is complicated by the fact that salt mining and brine pumping have also commonly occurred in the areas where natural dissolution has occurred.

A = Very Low, areas where salt is present, but the thickness of the deposits are known to be thin and covered with impervious material.

$\mathbf{B}=$ Low, areas where salt is present in substantial thicknesses, but where the deposits are covered with a significant thickness of impervious material, or areas where there is good evidence that the majority of the salt has dissolved.

C = Moderate, areas where salt is present in substantial thicknesses and present at rockhead (wet rockhead) or beneath a thin cover of impervious rock.

$\mathbf{D}=$ High, areas where salt is present in substantial thicknesses, present at rockhead (wet rockhead) and where salt springs are present in the area.

$\mathbf{E}=$ Very high, areas where salt is present in substantial thicknesses, present at rockhead (wet rockhead) and where wild brining or nearby mining has occurred, salt springs are present and there is some recorded subsidence in the vicinity; mainly the Triassic salt of Cheshire, Staffordshire and Worcestershire.

\section{Discussion}

Clearly, the GeoSure dataset only provides an indication of where dissolution features might occur, and does not give actual locations of karst features. Furthermore, the National Karst Database does not provide details of all karst features and neither dataset should be used as a substitute for detailed site investigation work, or a more detailed hazard assessment, such as that proposed by Edmonds (1983). Whether these karst geohazards constitute a potential risk depends on the views of the end user; for example, a cave might pose a problem for a construction company, but be a boon for a caving enthusiast, whereas an irregular rockhead might be a potential hazard to a construction company excavating a tunnel, but not pose a risk to a home owner whose house has good foundations.

Clearly, given the very localized nature of karst, not all areas categorized as being of high risk will suffer subsidence or contain karst features, and this uncertainty needs to be communicated. For house owners, the presence of a moderate or high dissolution rating (class $\mathrm{E}$ or $\mathrm{D}$ ) does not mean that any particular property will collapse or subside, but it acts as a warning that the geological conditions make the area prone to subsidence under certain circumstance, for example if leaking sewers or water pipes wash out clay-infilled dissolution pipes. Karst features are generally stable until exceptional circumstances such as severe flooding, or a burst water main occur (Fig. 8). Changes to the natural hydrological regime caused by changes in the nature of surface runoff, excavating or loading the ground, groundwater abstraction, leaking services and inappropriate drainage can also trigger subsidence in otherwise stable areas (Waltham et al., 2005). Neither of these datasets predict when such events will occur, but they can prove useful for a variety of individuals and organizations (Table 7).

Planners can utilize the datasets to inform the zoning of areas for development and building control, thus protecting the public from severe subsidence problems (Paukstys et al., 1999). 
Developers and geotechnical engineers can use the information to help with linear route planning, site design and hazard avoidance. Householders can be better informed about potential geological hazards when purchasing properties and be aware of situations that can aggravate the natural situation so that situations such as letting pipes leak, or emptying a swimming pool onto the garden and collapsing a house (Edmonds, 2005) can be avoided. For the insurance and financial industries the datasets can mean they are better informed about the potential risks they take, but except in exceptional circumstances the data should not be used as a reason for refusing to provide insurance, though it might justify a loading of the premium. Considering the sensitivity of karst to pollution, it is also important that the datasets provide both related baseline information (such as the locations of stream sinks and sinkholes) and generalized information about the susceptibility of specific geological units to develop karstic features. Finally, the datasets can be used to inform farmers and estate managers about their land and some of the constraints that they should consider when dealing with it.

\section{Acknowledgements}

Many thanks to Steve Thorpe, Nathan Williams, Amanda Richardson, Hannah Cullen and Sarah Doran, who entered much of the data. Keith Adlam is thanked for setting up the National Karst Database and GIS. Jenny Walsby is thanked for supporting the GeoSure project and Rhonda Newsham is thanked for processing data and providing GIS help. Dave Lowe and Vanessa Banks kindly read through the text and provided useful comments. Professor Martin Culshaw, Dr Tony Waltham and Dr Andy Gibson are thanked for their help. This paper is published with the permission of the Executive Director, British Geological Survey.

\section{References}

Applied Geology Limited, 1993. Review of instability due to natural underground cavities in Great Britain. Royal Leamington Spa, Applied Geology Ltd.

Chamberlain, A. T. \& Williams, J. P. 1999. A Gazetteer of English Caves, Fissures and Rock Shelters Containing Human Remains. Capra. 1. World Wide Web address: http://capra.group.shef.ac.uk/1/caves.html

Chamberlain, A. T. \& Williams, J. P. 2000a A Gazetteer of Scottish Caves, Fissures and Rock Shelters Containing Human Remains. Capra. 2. World Wide Web address: http://capra.group.shef.ac.uk/2/scotland.html

Chamberlain, A. T. \& Williams, J. P. 2000b A Gazetteer of Welsh Caves, Fissures and Rock Shelters Containing Human Remains. Capra. 2. World Wide Web address: http://capra.group.shef.ac.uk/2/wales.html

Cooper, A. H. 1986. Foundered strata and subsidence resulting from the dissolution of Permian gypsum in the Ripon and Bedale areas, North Yorkshire. In: Harwood, G M and Smith, D B (eds). The English Zechstein and related topics. Geological Society of London, Special Publications, 22, 127-139.

Cooper, A. H. 1989. Airborne multispectral scanning of subsidence caused by Permian gypsum dissolution at Ripon, North Yorkshire. Quarterly Journal of Engineering Geology, 22, 219-229.

Cooper, A. H. 1997. Gypsum karst of Great Britain. In: Klimchouk, A, Lowe, D, Cooper, A and Sauro, U (eds). Gypsum karst of the world. International Journal of Speleology, 5, 195-202.

Cooper, A H. 1998. Subsidence hazards caused by the dissolution of Permian gypsum in England: geology, investigation and remediation. In: Maund, J.G. and Eddleston, M (eds.) Geohazards in Engineering Geology. Geological Society, London, Engineering Special Publications, 15, 265-275.

Cooper, A. H. 2002. Halite karst geohazards (natural and man-made) in the United Kingdom. Environmental Geology, 42, 505-512. 
Cooper A. H \& Saunders, J. M. 1999. Road and bridge construction across gypsum karst in England. In: Beck, B., Pettit, A. J. \& Herring, G. (eds). Hydrogeology and engineering geology of sinkholes and karst 1999. Proceedings of the 7th multidisciplinary conference on sinkholes and the engineering and environmental impacts of karst. Harrisburg/Hershey, Pennsylvania. Balkema, Rotterdam, 407-411.

Cooper, A. H. \& Saunders, J M. 2002. Road and bridge construction across gypsum karst in England. Engineering Geology, 65, 217-223.

Cooper, A. H., Farrant, A. R., Adlam, K, \& Walsby, J C. (2001) The development of a national Geographic Information System (GIS) for British karst geohazards and risk assessment. In: Beck, B \& Herring, G. (eds). Geotechnical and Environmental Applications of Karst Geology and Hydrology. Proceedings of the $8^{\text {th }}$ Multidisciplinary conference on Sinkholes and the Engineering and Environmental Impacts of Karst. Louisville, Kentucky. Balkema. Lisse, 125-130.

Culshaw. M. G. \& Waltham, A. C. 1987. Natural and artificial cavities as ground engineering hazards. Quarterly Journal of Engineering Geology and hydrogeology, 20, 139-150.

Department of the Environment, 1990. Planning policy guidance note 14: Development on unstable land. HMSO, London

Department of Transport, Local Government and the Regions, 2002. Planning policy guidance note 14. Development on unstable land. Annex2: Subsidence and planning. The Stationary Office, London.

Edmonds, C. N. 1983. Towards the prediction of subsidence risk upon the Chalk outcrop. Quarterly Journal of Engineering Geology, 16, 261-266.

Edmonds, C. N. 2001. Predicting natural cavities in Chalk. Geological Society Engineering Special Publication 5, 205-214.

Edmonds, C. N. 2005. Subsidence over a chalk pipe at Chalfont St. Peter, UK. In: Waltham, A. C, Bell, F. G. \& Culshaw, M. G. (eds) Sinkholes and subsidence. Karst and cavernous rocks in engineering and construction. Praxis, Chichester. 309-312.

Farrant, A. R. 2001. Karst development in the Southern English Chalk. In: Beck, B \& Herring, G. (eds). Geotechnical and Environmental Applications of Karst Geology and Hydrology. Proceedings of the $8^{\text {th }}$ Multidisciplinary conference on Sinkholes and the Engineering and Environmental Impacts of Karst. Louisville, Kentucky. Balkema. Lisse, 7782.

Farrant, A. R. 2004. Ogof Draenen. In: Gunn, J. (ed). Encyclopedia of Cave and Karst Science. Fitzroy Dearborn. London.

Ford, T. D. (Ed). 1989. Limestones and Caves of Wales. Cambridge, Cambridge University Press.

Hindley, R. 1965. Sink-holes on the Lincolnshire limestone between Grantham and Stamford. The East Midland Geographer, 3, 454-460.

Klimchouk, A., Lowe, D., Cooper, A, \& Sauro, U. 1997. Gypsum karst of the world. International Journal of Speleology, 5, 307 pp.

Klimchouk, A. \& Lowe, D. 2002. Implications of speleological studies for karst subsidence hazard assessment; International Journal of Speleology, Vol. 31(1/4)

Lamont-Black, J., Younger, P. L., Forth, R. A., Cooper, A. \& Bonniface, J. 2002. A decision logic framework for investigating subsidence problems potentially attributable to gypsum karstification. Engineering Geology, 65, 205-215.

Lauritzen, S-E. 2001. Marble stripe karst of the Scandinavian Caledonides. An end member in the contact karst spectrum. Acta Carsologica, 30, 47-92. 
Lawson, T. J. (1988) The Limestone Caves of Scotland Part 2: Caves of Assynt. Grampian Speleological Group Occasional Publication 6, Edinburgh.

Notholt, A. J. G. \& Highley, D. E. 1973. Salt. Mineral Dossier No. 7, Mineral Resources Consultative Committee, HMSO. London, 36 p.

Oldham, A. D. 1975. The caves of Scotland, except Assynt. Bristol, Tony Oldham.

Oldham, A. D. Oldham, J. E. A. \& Smart, J. 1986. The concise caves of Devon. Crymyrch. Anne Oldham.

Paukštys, B., Cooper, A. H. \& Arustiene, J. 1999. Planning for gypsum geohazards in Lithuania and England. Engineering Geology, 52, 93-103.

Ryder, P F, \& Cooper, A H. 1993. A cave system in Permian gypsum at Houtsay Quarry, Newbiggin, Cumbria, England. Cave Science, 20, No. 1, 23-28.

Waltham, A. C., Simms, M. J., Farrant A. R. \& Goldie, H. (1997). Karst and Caves of Great Britain: Geological Conservation Review. Chapman and Hall. 358pp

Waltham, A. C., Bell, F. G. \& Culshaw, M. G. 2005. Sinkholes and subsidence. Karst and cavernous rocks in engineering and construction. Chichester, Praxis. 382 pp. 


\section{Figure captions:}

Fig. 1. Simplified map of the karstic rocks in the UK.

Fig. 2. A sinkhole formed after severe flooding in 1968 near Cheddar, Somerset [ST 4765 5620]. Superficial loessic cover sands have slumped into the underlying GB Cavern. An attempt was made to fill in the hole with old cars, which can still be seen in the cave below. Photo A Farrant, copyright NERC.

Fig. 3. Field geologist's field slip [OLL 131 NW (E)], compiled by F B A Welch, surveyed in 1941, describing a stream sink in the Upper Lincolnshire Limestone Member (Jurassic), near Burton-le-Coggles [SK 9683 2595], and its response to a flood. The railway line is the East Coast Main Line.

Fig. 4. A schematic cross section through the north crop of the South Wales coal-field, showing the relationships between the runoff margin and the feather edge zones along the contact between soluble and insoluble rocks. An area of interstratal karst occurs where the Twrch Sandstone overlies karstified Carboniferous Limestone.

Fig. 5. A large sinkhole and stream sink developed on the South Wales Lower Coal Measures Formation, Mynydd Llangattwg, South Wales [SO 1766 1527]. Subsidence here has been caused by the collapse of the Carboniferous Limestone at depth. The collapse column has migrated up more than $40 \mathrm{~m}$ through the overlying Twrch Sandstone Formation into the "Coal Measures". The water reappears in the Cascade Inlet in the 31km-long Agen Allwedd cave system, over $200 \mathrm{~m}$ below the surface. Photo A Farrant, copyright NERC.

Fig. 6(a). The digital 1:50 000 bedrock and superficial geological map of the North Hill area of the Mendip Hills, near Bristol [ST 540 514], with data from the National Karst Database superimposed; purple circles are caves or stream sinks, small green circles are sinkholes. The blue colours are the Carboniferous Limestone formations, the grey is the Avon Group (see Fig. 6b). North Hill comprises Devonian Portishead Formation (brown), with pink Triassic conglomerates to the north-east. A thin deposit of valley head runs along the dry valley though Priddy.

Fig. 6(b). The GeoSure hazard map for this area with data from the National Karst Database superimposed; purple circles are caves or stream sinks, small green circles are sinkholes. Much of the bare Carboniferous Limestone plateau gives a rating of C, although locally unmapped loessic cover sands give rise to higher densities of sinkholes north of Priddy. A thin zone around the margins of the Avon Group give a rating of $\mathrm{E}$, which is where the majority of the caves and stream sinks are found. Many suffosion sinkholes occur in the valley head deposits in Priddy which has a D rating. The Avon Group consists of a sequence of interbedded limestones and mudstones, which is weakly karstic overall, hence the A rating. The Triassic conglomerates to the north-east of North Hill host several significant cave systems and stream sinks, and are rated C, except along the margins of the Portishead Formation where it has a $\mathrm{D}$ rating.

Fig. 7. Sinkhole formed by the dissolution of Permian gypsum in the village of Sutton Howgrave [SE 3246 7928] near Ripon, North Yorkshire. The hole started to collapse in December 2000, the photograph was taken on February $14^{\text {th }} 2001$ when the hole was 5-6 $\mathrm{m}$ in diameter and $11 \mathrm{~m}$ deep with water at a depth of $8 \mathrm{~m}$. Photo A H Cooper, copyright NERC.

Fig. 8. Numerous sinkholes formed by a large burst water main at Littleheath Road, Fontwell, Sussex [SU 944 077] in late 1985. At least 63 collapses are visible, 8 in gardens, 4 on the road and the remainder in the field. The burst water main was near the digger in the top right of the view. The site is on solifluction deposits overlying Culver Chalk, close to the Palaeogene margin. Photo copyright Sealand Aerial, Chichester, reproduced under licence.

Table 1. Datafields gathered for sinkholes 
Table 2. Datafields gathered for springs

Table 3. Datafields gathered for stream sinks

Table 4. Datafields gathered for natural cavities

Table 5. Datafields gathered for property damage

Table 6. Superficial deposit domain groupings

Table 7. Suggested text to accompany hazard ratings tailored for different potential end users. 
Figures

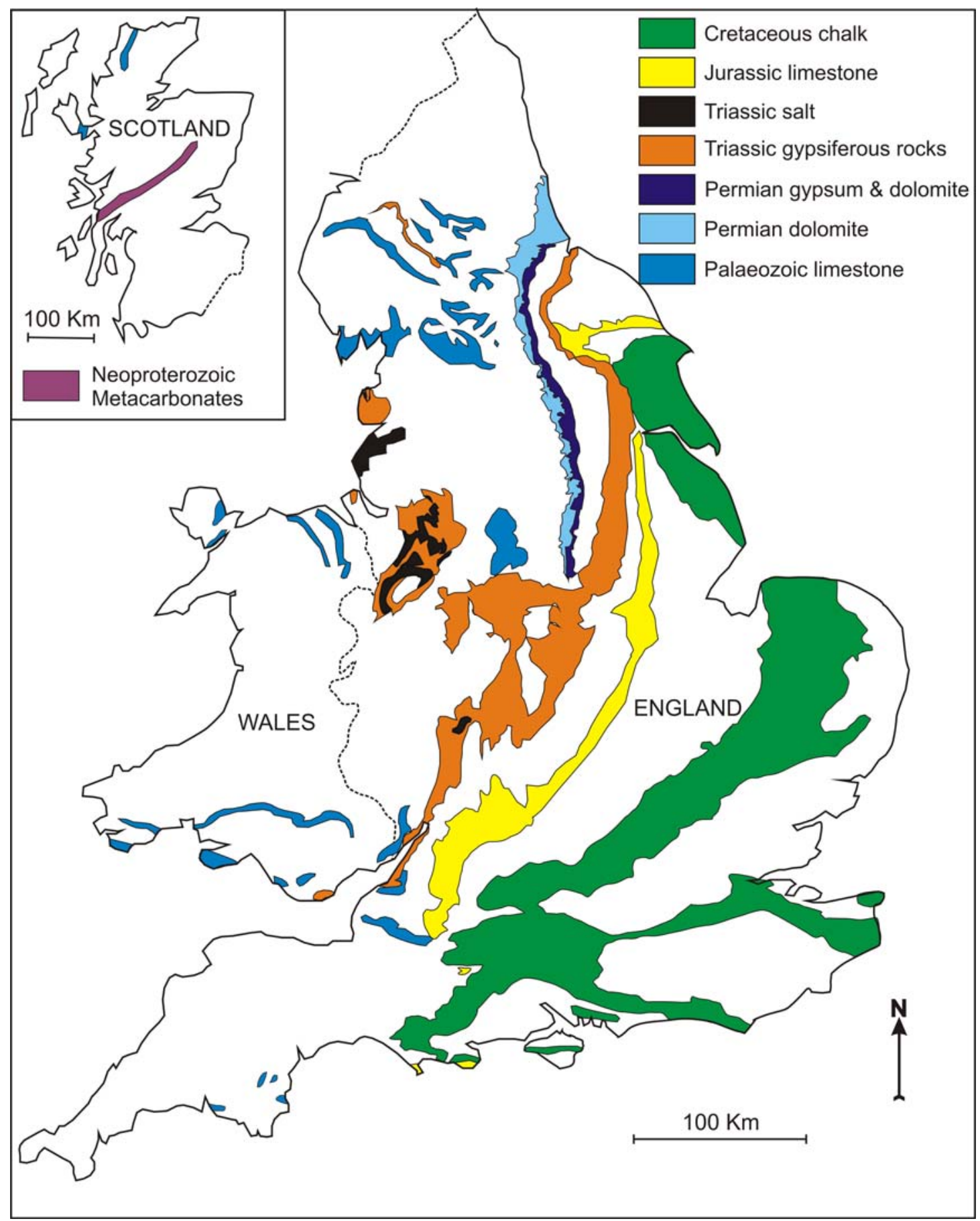

Fig. 1. Simplified map of the karstic rocks in the UK. 


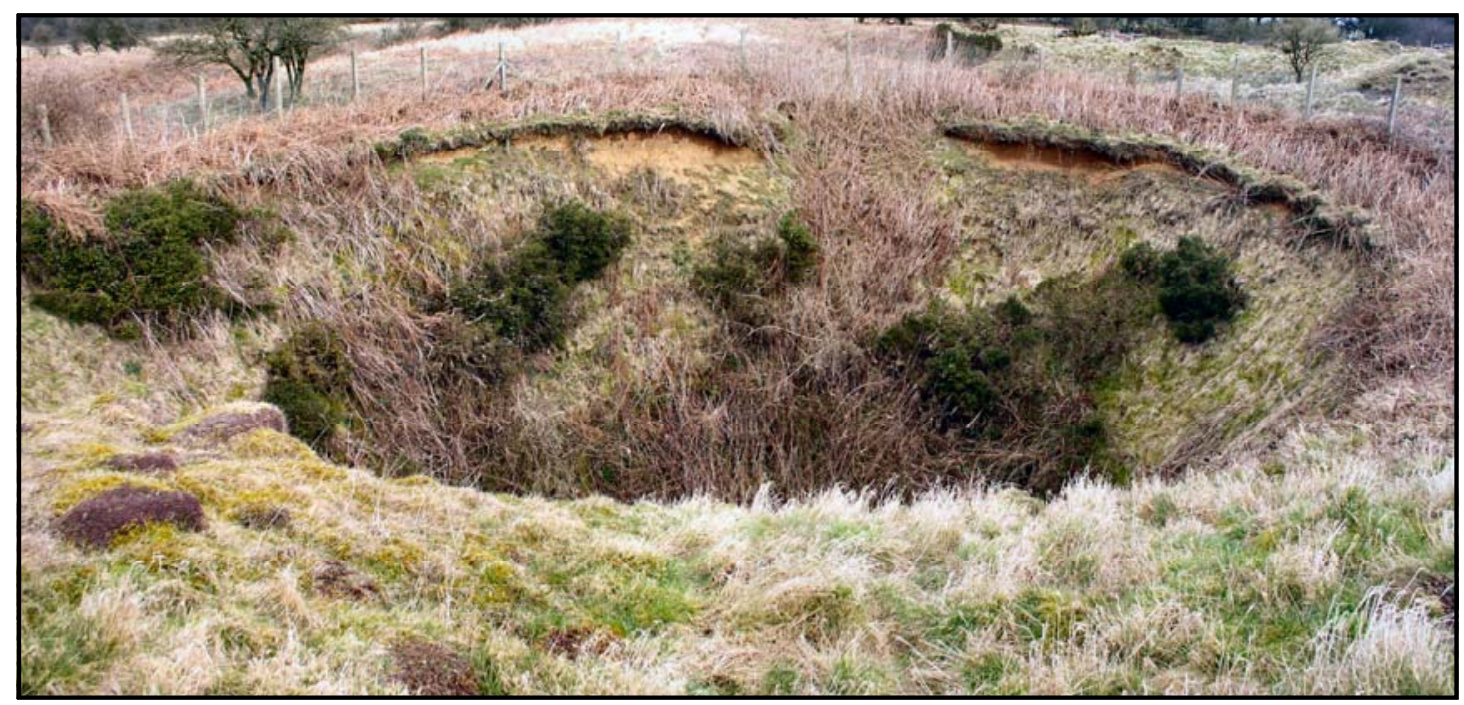

Fig. 2. A sinkhole formed after severe flooding in 1968 near Cheddar, Somerset [ST 4765 5620]. Superficial loessic cover sands have slumped into the underlying GB Cavern. An attempt was made to fill in the hole with old cars, which can still be seen in the cave below. Photo A. Farrant, copyright NERC.

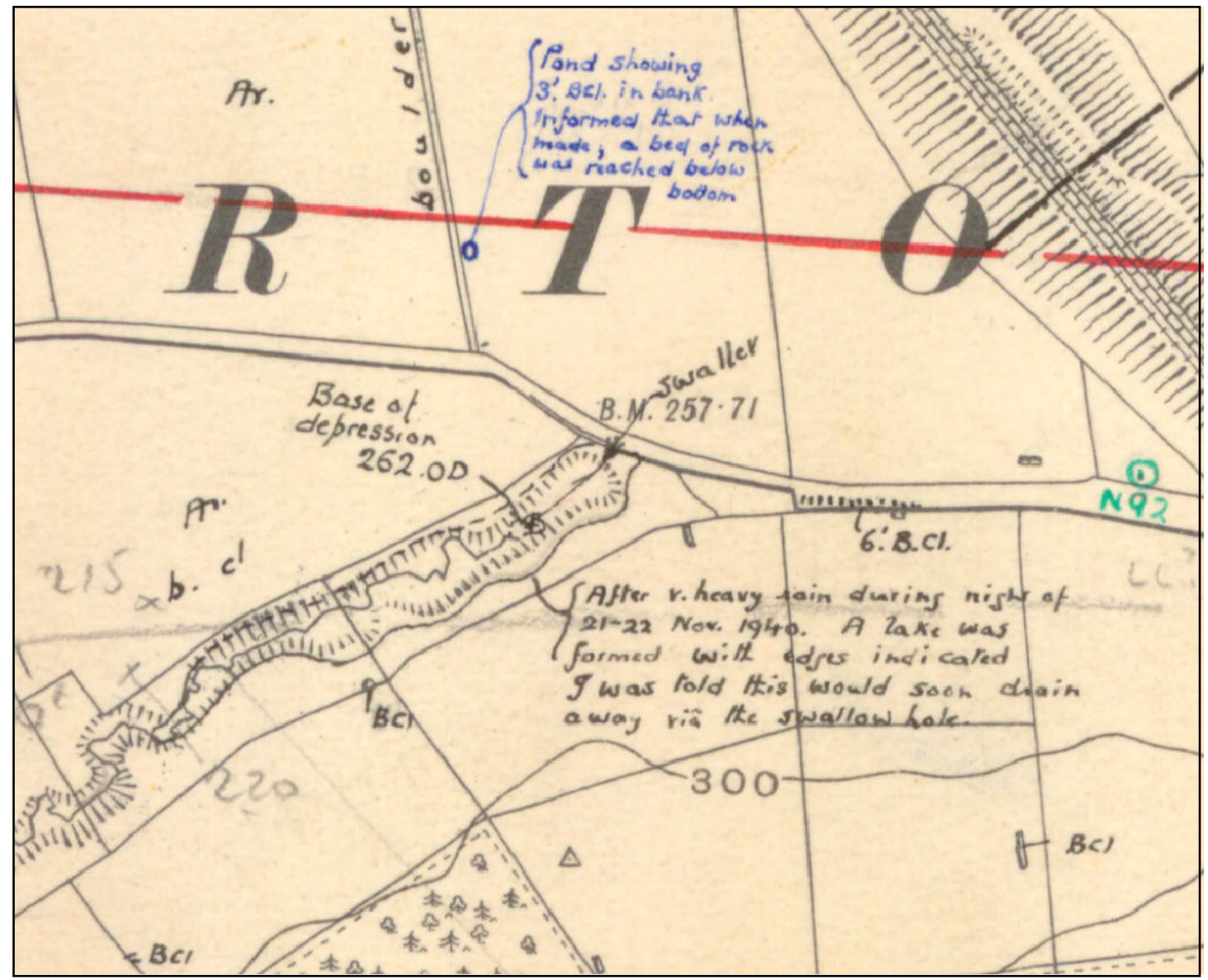

Fig. 3. Field geologist's field slip [OLL 131 NW (E)], compiled by F B A Welch, surveyed in 1941, describing a stream sink in the Upper Lincolnshire Limestone Member (Jurassic), near Burton-le-Coggles [SK 9683 2595], and its response to a flood. The railway line is the East Coast Main Line. 


\begin{tabular}{|l|l|}
\hline Sinkholes, record item & Parameters \\
\hline Sinkhole Name & Free text \\
\hline Size & Size x, Size y, Size z, meters. \\
\hline Type & Compound, collapse, suffusion, solution, no data, buried \\
\hline Shape & Round, oval, irregular, modified, compound, no data \\
\hline Surface profile & Pipe, cone, inverted cone, saucer, complex, levelled (filled), no data \\
\hline Infill deposits & British Geological Survey rock and stratigraphical codes with thicknesses \\
\hline Subsidence type & Gradual, episodic, instantaneous, no data \\
\hline Evidence of quarrying & Yes, no, no data \\
\hline Primary data source & Field mapping, air-photo, site-investigation, database, maps and surveys, \\
\hline Reliability & literature, Lidar remote sensing, Applied Geology database, no data \\
\hline Property damage & Good, probable, poor, no data \\
\hline Oldest recorded subsidence & Yes, no, no data \\
\hline Intermediate subsidence events & dd/mm/yyyy \\
\hline Most recent subsidence & dd/mm/yyyy \\
\hline Other data & dd/mm/yyyy \\
\hline References & Free text \\
\hline
\end{tabular}

Table 1. Datafields gathered for sinkholes 


\begin{tabular}{|l|l|}
\hline Springs, record item & Parameters \\
\hline Spring Name & Free text \\
\hline Elevation & Metres. \\
\hline Situation & $\begin{array}{l}\text { Open surface, borehole, concealed, submerged, submarine, underground } \\
\text { inlet, no data }\end{array}$ \\
\hline Proven dye trace & Yes, no \\
\hline Flow & $\begin{array}{l}\text { Ephemeral, fluctuating, constant, flood overflow, ebbing and flowing,no } \\
\text { data }\end{array}$ \\
\hline Water type & Normal/fresh, saline, sulfate, tufaceous, other mineral, no data \\
\hline Size & $\begin{array}{l}\text { Trickle, small stream, medium stream, large stream, small river, medium } \\
\text { river, large river, no data }\end{array}$ \\
\hline Primary data source & $\begin{array}{l}\text { Field mapping, air-photo, site-investigation, database, maps and surveys, } \\
\text { literature, Lidar remote sensing, DoE database, no data }\end{array}$ \\
\hline Artesian & Yes, no, no data \\
\hline Thermal & Yes, no, no data \\
\hline Karstic & Yes, no, no data \\
\hline Uses & None, public, agricultural, industrial, other, no data \\
\hline Character & Single discrete, multiple discrete, diffuse, no data \\
\hline Reliability & Good, probable, poor, no data \\
\hline Estimated discharge & Litres per second (l s-1 $)$ \\
\hline Other data & dd/mm/yyyy \\
\hline References & Free text \\
\hline
\end{tabular}

Table 2. Datafields gathered for springs

\begin{tabular}{|l|l|}
\hline Stream sinks; record item & Parameters \\
\hline Sink name & Free text \\
\hline Elevation Meters & Proven dye traces Yes, no, no data \\
\hline Morphology & $\begin{array}{l}\text { Discrete compound, discrete single sink, diffuse sink, losing stream,, } \\
\text { ponded sink, cave entrance, concealed sink, no data }\end{array}$ \\
\hline Flow & Perennial, intermittent, ephemeral (flood), Estavelle, no data \\
\hline Size & $\begin{array}{l}\text { Trickle, small stream, medium stream, large stream, small river, medium } \\
\text { river, large river, no data }\end{array}$ \\
\hline Primary data source & $\begin{array}{l}\text { Field mapping, air-photo, site-investigation, database, maps and surveys, } \\
\text { literature, Lidar remote sensing, DoE database, no data }\end{array}$ \\
\hline Reliability & Good, probable, poor, no data \\
\hline Estimated discharge & Litres per second (l s-1) \\
\hline Other data & Free text \\
\hline References & Free text \\
\hline
\end{tabular}

Table 3. Datafields gathered for stream sinks 


\begin{tabular}{|l|l|}
\hline Natural Cavities, record item & Parameters \\
\hline Cavity name & Free text \\
\hline Length & Metres \\
\hline Vertical range & Metres \\
\hline Elevation & Metres \\
\hline Type & $\begin{array}{l}\text { Open cave natural, infilled cave natural, gull cave, lava tube, boulder, peat } \\
\text { cave, sea cave, stoping cavity, palaeokarst, hydrothermal borehole cavity, } \\
\text { no data }\end{array}$ \\
\hline $\begin{array}{l}\text { Rock units penetrated (bedrock and } \\
\text { superficial) }\end{array}$ & British Geological Survey rock and stratigraphical codes \\
\hline Primary data source & $\begin{array}{l}\text { Field mapping, air-photo, site-investigation, database, maps and surveys, } \\
\text { literature, Lidar remote sensing, DoE database, no data }\end{array}$ \\
\hline Streamway & Yes, no, no data \\
\hline Other entrance & Yes, no, no data \\
\hline Evidence of mining & Yes, no, no data \\
\hline Reliability & Good, probable, poor, no data \\
\hline Other data & Free text \\
\hline References & Free text \\
\hline
\end{tabular}

Table 4. Datafields gathered for natural cavities

\begin{tabular}{|l|l|}
\hline Property damage, record item & Parameters \\
\hline Address & Free text \\
\hline Postcode & Postcode format \\
\hline Elevation & Metres \\
\hline Damage survey 1 & Date (dd/mm/yyyy), notes, damage rating (1-7) \\
\hline Damage survey & 2 Date (dd/mm/yyyy), notes, damage rating (1-7) \\
\hline Damage survey 3 & Date (dd/mm/yyyy), notes, damage rating (1-7) \\
\hline Suspected cause & $\begin{array}{l}\text { Natural subsidence, mining subsidence, landslip, compressible fill, } \\
\text { building defect }\end{array}$ \\
\hline Reliability & Good, probable, poor, no data \\
\hline Other data & Free text \\
\hline References & Free text \\
\hline
\end{tabular}

Table 5. Datafields gathered for property damage 


\begin{tabular}{|l|l|}
\hline Unmantled Domain: & Areas with no superficial cover, or where the cover has been eroded away. \\
\hline Marine Domain. & All marine and intertidal superficial deposits. \\
\hline Raised Beach Domain. & All types of raised beach deposits \\
\hline River Valley Domain. & Fluvial deposits such as alluvium, valley peat and valley gravels. \\
\hline River Terrace Domain. & All types of river terrace deposits \\
\hline $\begin{array}{l}\text { Weathered Mantled } \\
\text { Domain. }\end{array}$ & $\begin{array}{l}\text { Residual and or weathering deposits such as the clay-with-flints, loessic } \\
\text { deposits and cover-sands, and hill peat. }\end{array}$ \\
\hline Dry Valley Domain & Head, Coombe and valley gravels \\
\hline Glacial Domain & Tills and glacial moraine deposits. \\
\hline
\end{tabular}

Table 6. Superficial deposit domain groupings 


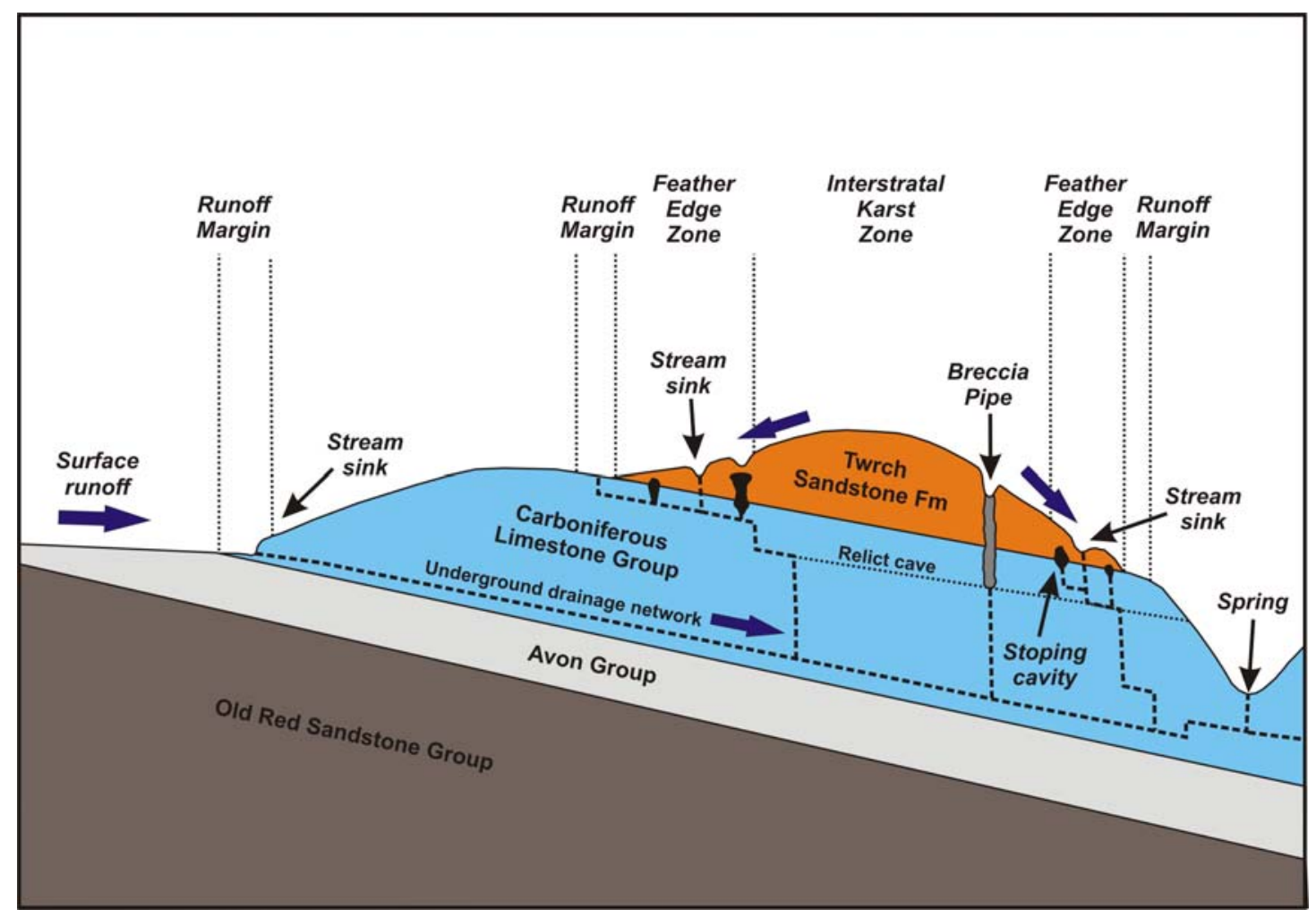

Fig. 4. A schematic cross section through the north crop of the South Wales coal-field, showing the relationships between the runoff margin and the feather edge zones along the contact between soluble and insoluble rocks. An area of interstratal karst occurs where the Twrch Sandstone overlies karstified Carboniferous Limestone. 


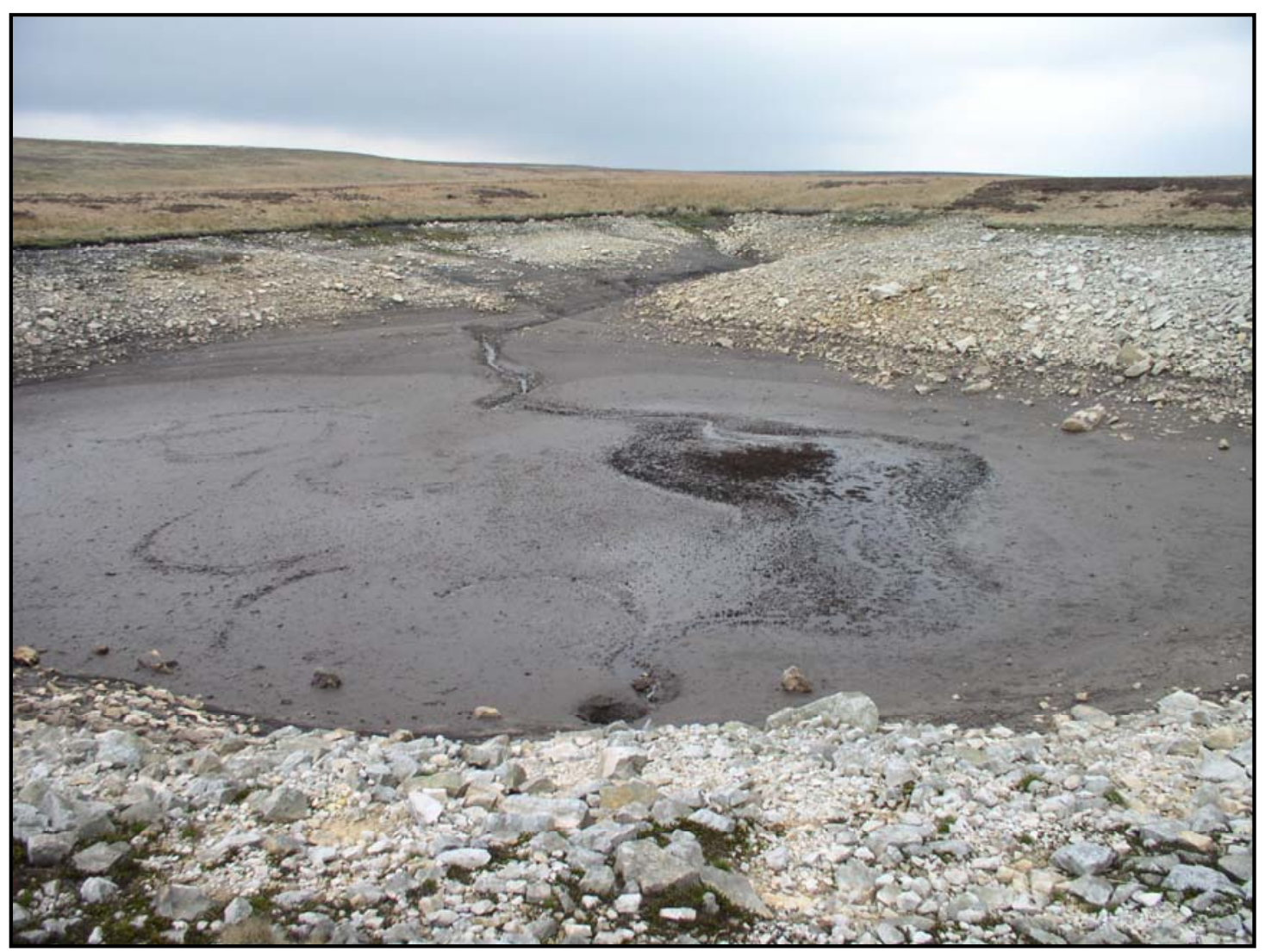

Fig. 5. A large sinkhole and stream sink developed on the Lower Coal Measures, Mynydd Llangattwg, South Wales [SO 1766 1527]. Subsidence here has been caused by the collapse of the Carboniferous Limestone at depth. The collapse column has migrated up over $40 \mathrm{~m}$ through the overlying Twrch Sandstone Fm into the Coal Measures. The water reappears in the Cascade Inlet in the $31 \mathrm{~km}$ long Agen Allwedd cave system, over $200 \mathrm{~m}$ below the surface. Photo A Farrant, copyright NERC. 


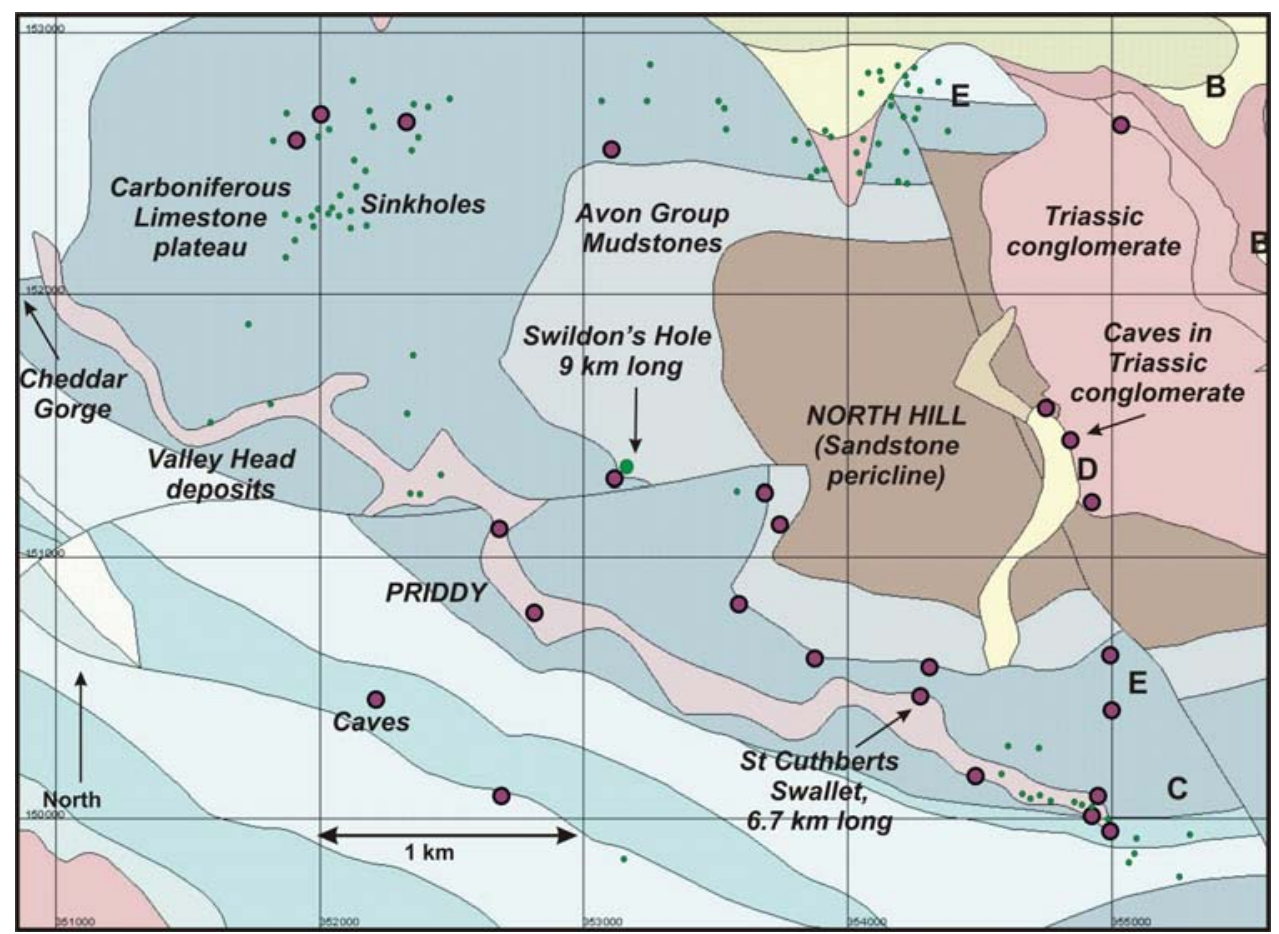

Fig. 6(a). The digital 1:50 000 bedrock and superficial geological map of the North Hill area of the Mendip Hills, near Bristol [ST 540 514], with data from the National Karst Database superimposed; purple circles are caves or stream sinks, small green circles are sinkholes. The blue colours are the Carboniferous Limestone formations, the grey is the Avon Group (see Fig. 6b). North Hill comprises Devonian Portishead Formation (brown), with pink Triassic conglomerates to the north-east. A thin deposit of valley head runs along the dry valley though Priddy.

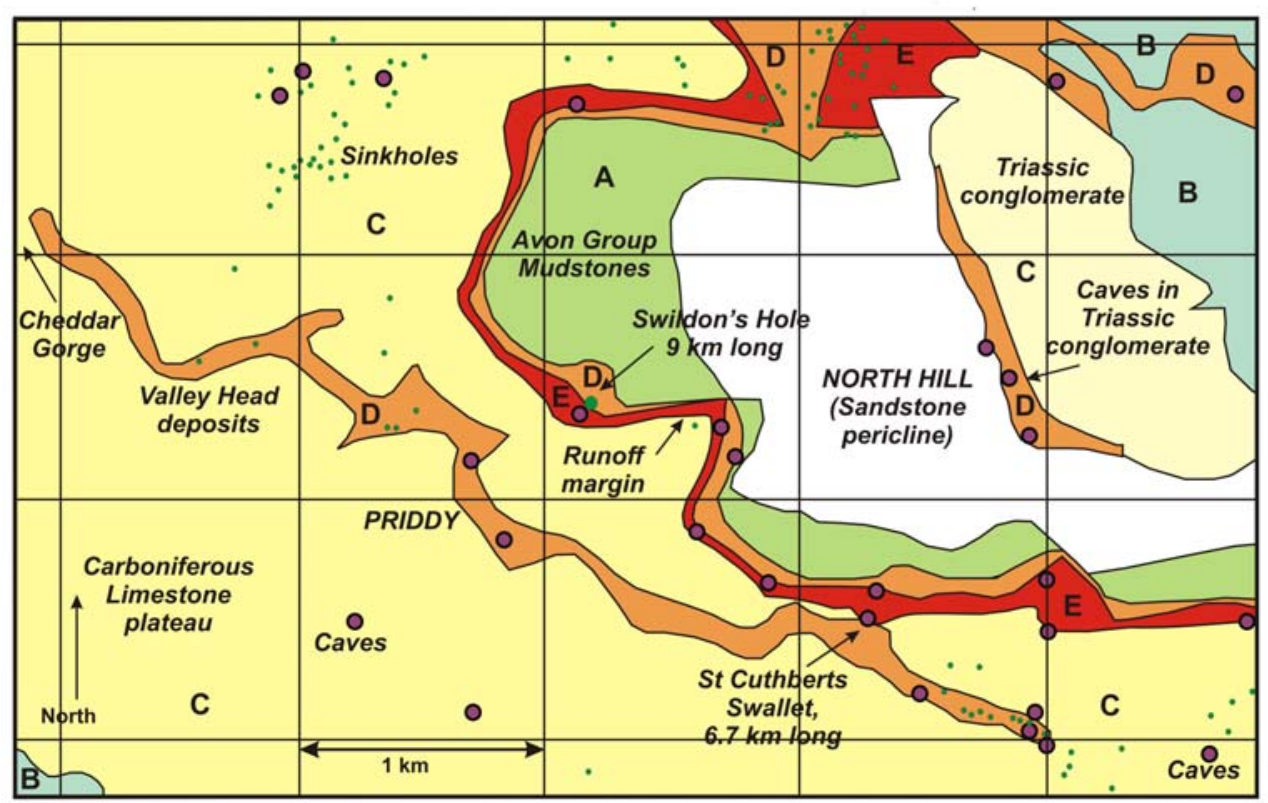

Fig. 6(b). The GeoSure hazard map for this area with data from the National Karst Database superimposed; purple circles are caves or stream sinks, small green circles are sinkholes. Much of the bare Carboniferous Limestone plateau gives a rating of C, although locally unmapped loessic cover sands give rise to higher densities of sinkholes north of Priddy. A 
thin zone around the margins of the Avon Group give a rating of E, which is where the majority of the caves and stream sinks are found. Many suffosion sinkholes occur in the valley head deposits in Priddy, which has a D rating. The Avon Group consists of a sequence of interbedded limestones and mudstones, which is weakly karstic, hence the A rating. The Triassic conglomerates to the north-east of North Hill host several significant cave systems and stream sinks, and are rated $\mathrm{C}$, except along the margins of the Portishead Formation where it has a D rating.

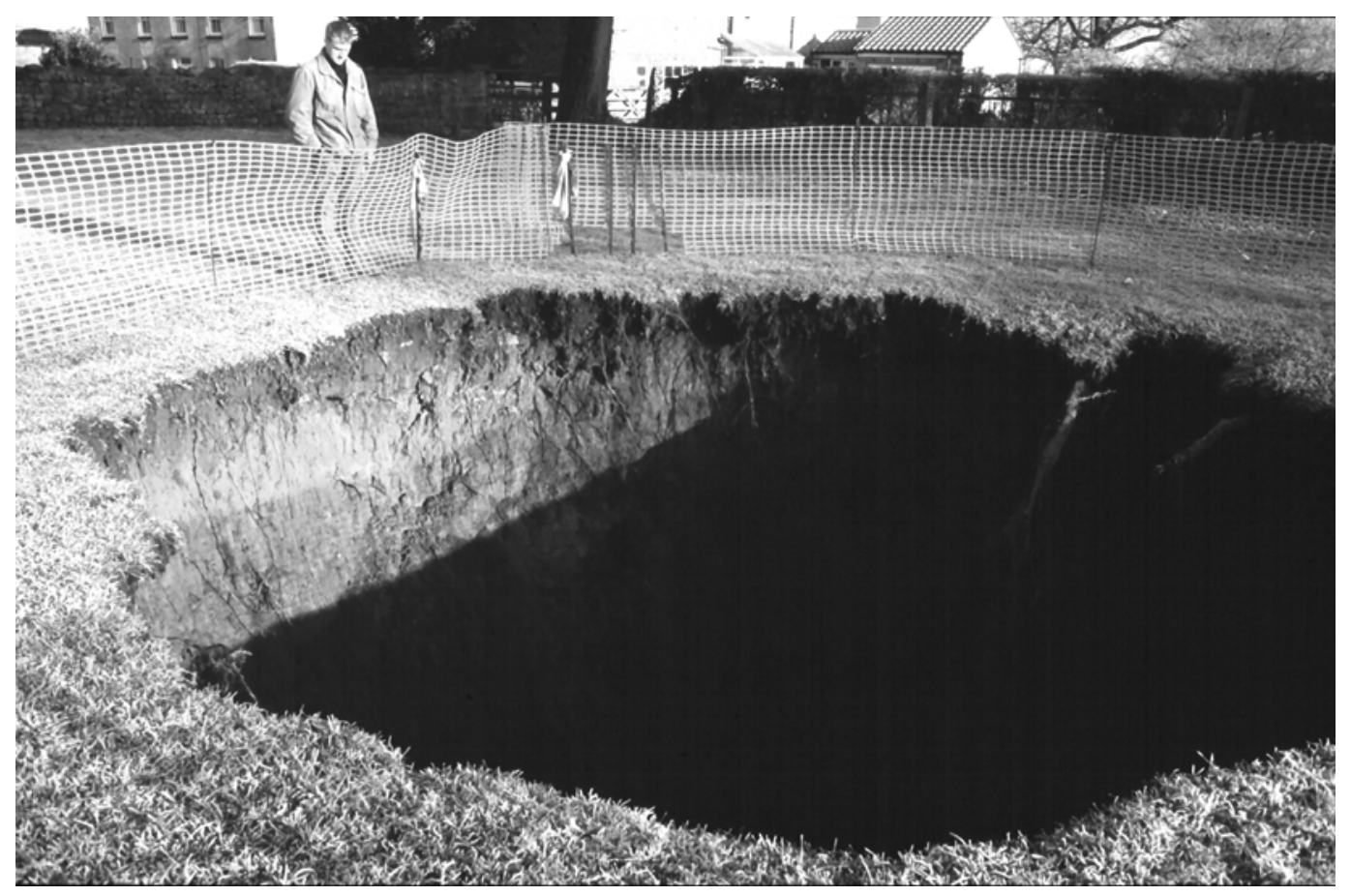

Fig. 7. Sinkhole formed by the dissolution of Permian gypsum in the village of Sutton Howgrave [SE 3246 7928] near Ripon, North Yorkshire. The hole started to collapse in December 2000, the photograph was taken on February $14^{\text {th }} 2001$ when the hole was 5-6 $\mathrm{m}$ in diameter and $11 \mathrm{~m}$ deep with water at a depth of $8 \mathrm{~m}$. Photo A H Cooper, copyright NERC. 


\begin{tabular}{|c|c|c|c|c|c|c|c|}
\hline \multirow{2}{*}{$\begin{array}{l}\text { Hazard } \\
\text { rating }\end{array}$} & \multirow[t]{2}{*}{ General characteristics } & \multicolumn{6}{|l|}{ Indicative implications for:- } \\
\hline & & Planners & $\begin{array}{c}\text { Developers/ } \\
\text { Geotechnical Engineers }\end{array}$ & House holders & $\begin{array}{c}\text { Insurance/Financial } \\
\text { Institutions }\end{array}$ & $\begin{array}{c}\text { Environmental } \\
\text { Health/Waste disposal }\end{array}$ & $\begin{array}{c}\text { Farmers and Estate } \\
\text { managers }\end{array}$ \\
\hline 1 or $\mathrm{A}$ & $\begin{array}{l}\text { Areas where soluble rocks are } \\
\text { present, but unlikely to cause } \\
\text { problems except under } \\
\text { exceptional conditions. }\end{array}$ & $\begin{array}{l}\text { No constraints to land use due } \\
\text { to land instability within site. }\end{array}$ & $\begin{array}{l}\text { Normal desk study and } \\
\text { walkover survey of site. }\end{array}$ & $\begin{array}{l}\text { No maintenance or use } \\
\text { implications due to land } \\
\text { instability }\end{array}$ & $\begin{array}{l}\text { No increased cost due } \\
\text { to land instability } \\
\text { present. }\end{array}$ & $\begin{array}{l}\text { Possible concern about } \\
\text { groundwater } \\
\text { contamination. }\end{array}$ & $\begin{array}{l}\text { No restrictions on land } \\
\text { use due to land } \\
\text { instability, concerns } \\
\text { about groundwater } \\
\text { contamination }\end{array}$ \\
\hline 2 or $\mathrm{B}$ & $\begin{array}{l}\text { Areas with significant soluble } \\
\text { rocks, but few dissolution features } \\
\text { and no subsidence; unlikely to } \\
\text { cause problems except with } \\
\text { considerable surface or subsurface } \\
\text { water flow. }\end{array}$ & $\begin{array}{l}\text { No constraints to land use due } \\
\text { to land instability within site. }\end{array}$ & $\begin{array}{l}\text { Normal desk study and } \\
\text { walkover survey of site. } \\
\text { Consideration of stability of } \\
\text { site surroundings }\end{array}$ & $\begin{array}{l}\text { No maintenance or use } \\
\text { implications due to land } \\
\text { instability }\end{array}$ & $\begin{array}{l}\text { Increased cost due to } \\
\text { land instability } \\
\text { unlikely. Slight } \\
\text { liability due to } \\
\text { groundwater pollution } \\
\text { possible }\end{array}$ & $\begin{array}{l}\text { Concern about } \\
\text { groundwater } \\
\text { contamination. }\end{array}$ & $\begin{array}{l}\text { No restrictions on land } \\
\text { use due to land } \\
\text { instability, concerns } \\
\text { about groundwater } \\
\text { contamination }\end{array}$ \\
\hline 3 or $\mathrm{C}$ & $\begin{array}{l}\text { Areas with significant soluble } \\
\text { rocks, where there are dissolution } \\
\text { features, and no or very little } \\
\text { recorded subsidence, but a low } \\
\text { possibility of it occurring } \\
\text { naturally or in adverse conditions } \\
\text { such as high surface or subsurface } \\
\text { water flow. }\end{array}$ & $\begin{array}{l}\text { Report on implications for } \\
\text { stability should be submitted if } \\
\text { changes to surface drainage or } \\
\text { new construction are proposed. }\end{array}$ & $\begin{array}{l}\text { Site investigation should } \\
\text { consider specifically the land } \\
\text { stability of the site and } \\
\text { surroundings. Care should be } \\
\text { taken with local drainage into } \\
\text { the bedrock. }\end{array}$ & $\begin{array}{l}\text { Consideration of } \\
\text { implications for stability } \\
\text { should be made if changes } \\
\text { to surface drainage or new } \\
\text { construction are planned. }\end{array}$ & $\begin{array}{l}\text { Increased cost due to } \\
\text { land instability } \\
\text { possible. Some } \\
\text { liability due to } \\
\text { groundwater pollution } \\
\text { possible }\end{array}$ & $\begin{array}{l}\text { Potential for site integrity } \\
\text { to be damaged by minor } \\
\text { ground movements. } \\
\text { Concern about } \\
\text { groundwater } \\
\text { contamination. }\end{array}$ & $\begin{array}{l}\text { Consider minor changes } \\
\text { in land use, surface run- } \\
\text { off and drainage to } \\
\text { prevent groundwater } \\
\text { contamination and } \\
\text { reduce the likelihood of } \\
\text { subsidence. }\end{array}$ \\
\hline 4 or D & $\begin{array}{l}\text { Areas with very significant } \\
\text { soluble rocks, where there are } \\
\text { numerous dissolution features } \\
\text { and/or some recorded subsidence } \\
\text { with a moderate possibility of } \\
\text { localized subsidence occurring } \\
\text { naturally or in adverse conditions } \\
\text { such as high surface or subsurface } \\
\text { water flow. }\end{array}$ & $\begin{array}{l}\text { Land use changes involving, } \\
\text { loading, infilling, excavation or } \\
\text { changes to surface drainage } \\
\text { may affect stability and } \\
\text { assessment/mitigation measures } \\
\text { should accompany application. } \\
\text { Conservation measures should } \\
\text { be considered. }\end{array}$ & $\begin{array}{l}\text { Specialist site investigation for } \\
\text { stability assessment might be } \\
\text { necessary before construction. } \\
\text { Construction work might cause } \\
\text { subsidence. Surface drainage } \\
\text { should not be allowed to affect } \\
\text { the karst system or } \\
\text { groundwater. }\end{array}$ & $\begin{array}{l}\text { Do not load the land, and } \\
\text { obtain specialist advice } \\
\text { before undertaking } \\
\text { building work. Do not } \\
\text { dispose of surface drainage } \\
\text { to the ground. Maintain } \\
\text { drainge infrastructure. }\end{array}$ & $\begin{array}{l}\text { Increased cost due to } \\
\text { land instability } \\
\text { probable. Liability due } \\
\text { to groundwater } \\
\text { pollution possible }\end{array}$ & $\begin{array}{l}\text { Possible damage to } \\
\text { contaminative structures, } \\
\text { tanks, drainage, sewers, } \\
\text { pipelines, etc. Inspection of } \\
\text { structures recommended. } \\
\text { Areas prone to pollution } \\
\text { and groundwater } \\
\text { contamination. }\end{array}$ & $\begin{array}{l}\text { Consider some changes } \\
\text { in land use, surface run- } \\
\text { off and drainage to } \\
\text { prevent groundwater } \\
\text { contamination and } \\
\text { reduce the likelihood of } \\
\text { subsidence }\end{array}$ \\
\hline 5 or $\mathrm{E}$ & $\begin{array}{l}\text { Areas with very significant } \\
\text { soluble rocks, where there are } \\
\text { numerous dissolution features } \\
\text { and/or considerable recorded } \\
\text { subsidence with a high possibility } \\
\text { of localized subsidence occurring } \\
\text { naturally or in adverse conditions } \\
\text { such as high surface or subsurface } \\
\text { water flow. }\end{array}$ & $\begin{array}{l}\text { Land use changes involving, } \\
\text { loading, infilling, excavation or } \\
\text { changes to surface drainage } \\
\text { may affect stability. } \\
\text { Permission for development } \\
\text { might require investigation and } \\
\text { remedial works as part of } \\
\text { development. Permission for } \\
\text { development might not be } \\
\text { possible. Conservation } \\
\text { measures should be considered. }\end{array}$ & $\begin{array}{l}\text { Specialist land stability } \\
\text { assessment necessary. } \\
\text { Investigation, remediation } \\
\text { and/or mitigation works might } \\
\text { be necessary to stabilize the } \\
\text { area. Construction work might } \\
\text { cause subsidence. Surface } \\
\text { drainage must not affect the } \\
\text { karst system or groundwater. }\end{array}$ & $\begin{array}{l}\text { Consider obtaining } \\
\text { specialist advice to advise } \\
\text { on need for stabilization } \\
\text { work and/or land } \\
\text { management plan to } \\
\text { maintain stability. Do not } \\
\text { dispose of surface drainage } \\
\text { into the ground. Maintain } \\
\text { drainage infrastructure. }\end{array}$ & $\begin{array}{l}\text { Increased cost due to } \\
\text { land instability very } \\
\text { probable. Liability due } \\
\text { to groundwater } \\
\text { pollution probable. }\end{array}$ & $\begin{array}{l}\text { Significant possibility of } \\
\text { damage to contaminative } \\
\text { structures, tanks, drainage, } \\
\text { sewers, pipelines, etc. } \\
\text { Regular inspection of } \\
\text { structures recommended. } \\
\text { Areas very prone to } \\
\text { pollution and groundwater } \\
\text { contamination. }\end{array}$ & $\begin{array}{l}\text { Consider major changes } \\
\text { in land use, surface run- } \\
\text { off and drainage to } \\
\text { prevent groundwater } \\
\text { contamination and } \\
\text { reduce the likelihood of } \\
\text { subsidence }\end{array}$ \\
\hline
\end{tabular}

Table 7. Suggested text to accompany hazard ratings tailored for different potential end users. 


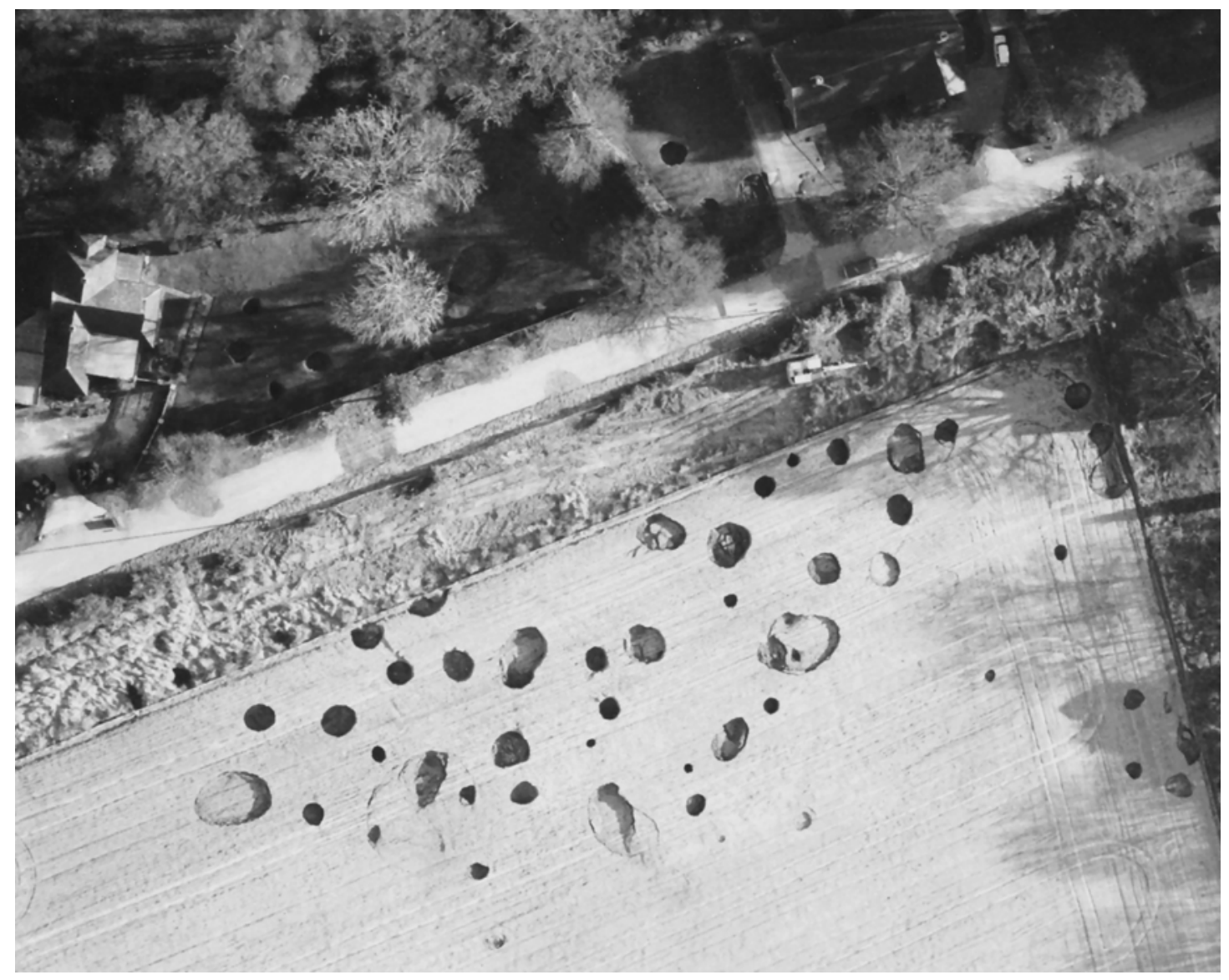

Fig. 8. Numerous sinkholes formed by a large burst water main at Littleheath Road, Fontwell, Sussex [SU 944 077] in late 1985. At least 63 collapses are visible, 8 in gardens, 4 on the road and the remainder in the field. The burst water main was near the digger in the top right of the view. The site is on solifluction deposits overlying Culver Chalk, close to the Palaeogene margin. Photo copyright Sealand Aerial, Chichester, reproduced under licence. 